\title{
Improving Performance of Universities Using University Rankings. \\ Case Study, Al Farabi Kazakh National University, Kazakhstan
}

\author{
Paul Șerban Agachi \\ Botswana International University of Science and Technology (BIUST), \\ Botswana, \\ Babeș-Bolyai University (BBU), Cluj-Napoca, Romania, \\ Member of the International Ranking Expert Group Executive Committee \\ agachip@biust.ac.bw
}

\begin{abstract}
Starting from personal experience and expertise, this article discusses the relevance of international rankings for improving the individual performance of universities. After analyzing the most relevant indicators used by one such ranking, the article suggests possible solutions to be considered by one individual university (i.e. Al Farabi Kazakh National University) if it aims to improve its position in international league tables and the quality of the processes in the university. At the same time, the article debates the degree to which the indicators used by the afore-mentioned international ranking are still relevant and can still be useful at institutional level, for university leaders.
\end{abstract}

Keywords: rankings, league tables, higher education performance indicator, higher education reform, Al Farabi Kazakh National University 


\section{Preamble}

In 2000, as a member of the Quality Management Council in Romania, we presented in The Rector's Conference, together with Professor Nica Panaite from Alexandru Ioan Cuza University, our conclusions about the needed metrics to assess the performance of the universities (Nica 2000: 68-237). In 2005, at the initiative of CEPES (UNESCO Centre Europeen pour Enseignement Superieur) in Bucharest, we initiated with the personal involvement of Prof. Jan Sadlak, the first initiative of a Romanian ranking of universities (Agachi \& Moraru 2005). In 2006, at the initiative of the Romanian Research Council for University Research (CNCSIS), we produced the first ranking of the Romanian universities (Agachi, Moraru, Mihaila \& Nica 2007; Agachi, Moraru, Cramarenco, Curaj 2009).

In the Dean's Conference in Barcelona, held at the initiative of European Strategic Management for Universities (ESMU), I explained "How you can convince a university to try to become research intensive" (Agachi 2008) and in 2009, I was invited by UNICA Conference in Dubrovnik, to present the point of view of International Ranking Expert Group (IREG) regarding university rankings (Agachi 2009).

This presentation was made based on the experience I had in Babeș-Bolyai University with the program BBU 500 (Agachi \& Bucur 2009). In 2011, in Brussels I explained to the academic community representatives how can we make the university rankings useful (Agachi 2011). In 2012, at the AUF Conference in Bucharest, "La fin des classements? De la compétition à la coopération universitaire" (what a doomsday they announced!) I represented - IREG - and tried to explain to the francophone world of universities that rankings, in spite of their limits and simplicity, are useful. In 2013, at WCU $-5^{\text {th }}$ Conference in Shanghai, as counselor of the Rector of the University of Bucharest, we presented a paper about how we can improve the situation in the University of Bucharest (Agachi, Nica \& Moraru 2012; Dumitru et all 2013).

The same year, the University of Debrecen, Hungary, invited me to present how their performance is seen and how it can improve. In 2015, I was asked by Al Farabi University in Almaty to help them understand 
their position in rankings and help them improve. In 2016, being at BIUST, I made a study on the positioning of the African universities in rankings, where the university from Botswana were placed and how they could improve their performances. And all this, in spite of the predictions that the "evil ranking movement" damages the quality of the universities (Rauhvargers 2011).

It is very important to understand what is behind the methodology of a ranking. The rankings measure some output indicators which they consider to be relevant for a certain goal; for example, from the beginning, the ARWU ranking (also known as the Shanghai ranking) was asked by the Chinese government to elaborate a methodology to assess which was the position of the Chinese universities in the world of higher education. Why? Because the Chinese government targeted the first economic position in the world to be reached in some 20 years and they were convinced that the nation can be built only through a higher education of the highest quality. And this is the reason why most indicators belong to the science and technology fields. Because the economic improvement was targeted!

I am writing this story, because I have noticed that, along the years, for a very long period, in spite of all the attacks on rankings, the question "how can universities improve based on university rankings" is still asked. The present paper presents a point of view on how the university management can fix some benchmarks for assessing the performance of the university's activities. No matter what one ranking might measure, one university cannot be "bad" in one ranking and "good" in another one. Because the good or bad performance is obtained in a good or bad environment in which values of ethics, transparency, engagement, institutional identification, recognition of merits are, or are not, cultivated.

In 2015, at the initiative of Al Farabi University in Almaty, Kazakhstan, I tried to carry out a study of how to use one ranking (the ranking in which they were well positioned) to improve the quality of the university's activities: teaching and learning, research, innovation, community engagement, internationalization. Al Farabi University is the oldest in Kazakhstan, being 75 years old, and it is a force in the higher education landscape in Central Asia (according to their own website). It has 2,500 academic staff, 18,000 students and aims to become one of the Top-200 research universities in the world. 
The QS WUR was the ranking in which the university was well positioned (ranked 305 in the world and 14 in Central Eastern EuropeCentral Asia). See Table 1.

The QS ranking is somehow commercial: many universities which are not present in the very exclusivist rankings such as THES or ARWU, have the ambition to be placed somewhere on the list. And their ambition has to be satisfied. And QS placed them on a list, inventing some indicators which allowed them to be present there. I do not state that those indicators are not at all relevant, but I admit that some of them can be either manipulated or improved through a well targeted policy which is not always related to the quality of the university activity.

The indicators of the QS ranking in 2014 are presented in Table 2. 
QS ranking for universities in Kazakhstan and other neighboring countries 2014

\begin{tabular}{|c|c|c|c|c|c|c|c|c|c|c|c|c|c|}
\hline $\begin{array}{l}\text { Name of the } \\
\text { university }\end{array}$ & $\begin{array}{l}\text { Co } \\
\text { unt }\end{array}$ & $\begin{array}{l}\text { Total } \\
\text { score }\end{array}$ & Rank & World $\mathrm{R}^{*}$ & $\begin{array}{l}\text { Academic } \\
\text { Reput/R }\end{array}$ & $\begin{array}{l}\text { Employer } \\
\text { Reput/R }\end{array}$ & $\begin{array}{l}\text { Faculty/ } \\
\text { Student/R }\end{array}$ & $\begin{array}{ll}\text { Staff } & \text { w. } \\
\mathrm{PhD} / \mathrm{R} & \end{array}$ & $\begin{array}{l}\text { Papers/ } \\
\text { Faculty/R }\end{array}$ & $\begin{array}{l}\text { Citations/ } \\
\text { Paper/R }\end{array}$ & $\begin{array}{l}\text { Intnl } \\
\text { Faculty/R }\end{array}$ & $\begin{array}{l}\text { Intnl } \\
\text { Stud/R }\end{array}$ & $\begin{array}{l}\text { Web } \\
\text { Impact/R }\end{array}$ \\
\hline Al Farabi Almaty & $\mathrm{KZ}$ & 75.6 & 14 & 305 & $99.8 / 3$ & $96.2 / 13$ & $77.3 / 32$ & $71.6 / 41$ & $5 / 101$ & $14.8 / 101$ & $85.2 / 13$ & $26.9 / 64$ & $24.2 / 77$ \\
\hline $\begin{array}{l}\text { Lev Gumiliov } \\
\text { Almaty }\end{array}$ & KZ & 71.6 & 23 & 324 & $95.1 / 10$ & $72.5 / 31$ & $99.6 / 7$ & 9.6/101 & $3.1 / 101$ & $40 / 96$ & $88.4 / 10$ & $16.4 / 90$ & $37.5 / 41$ \\
\hline KNTechU Almaty & $\mathrm{KZ}$ & 50 & $51-60$ & $601-650$ & - & - & $95.5 / 13$ & $18.1 / 101$ & $2.4 / 101$ & $3.3 / 101$ & $18.4 / 67$ & $14.2 / 95$ & $17.9 / 97$ \\
\hline KBTU Almaty & $\mathrm{KZ}$ & 48.8 & $51-60$ & $651-7010$ & - & - & $28.4 / 101$ & $68.3 / 49$ & $14.7 / 101$ & $10 / 101$ & $100 / 1$ & 2.9/101 & 7.5/101+ \\
\hline M.Auezov SKSU & $\mathrm{KZ}$ & 38.4 & $71-80$ & $651-700$ & - & - & $61.3 / 54$ & $38.8 / 101$ & $1.6 / 101$ & $3.9 / 101$ & $69.6 / 20$ & $22.8 / 73$ & $6.7 / 101+$ \\
\hline Ablai Khan Almaty & $\mathrm{KZ}$ & 35.1 & 81-90 & 701 & - & - & $45.1 / 86$ & $29.4 / 101$ & 0 & 0 & $48.7 / 27$ & $11.2 / 101$ & $1.9 / 101+$ \\
\hline Baku SU & $\mathrm{AZ}$ & 36.3 & 71-80 & 701 & - & - & $39.6 / 101$ & $13.3 / 101$ & 19.8/101 & $11.6 / 84$ & $16.8 / 87$ & $1.4 / 101+$ & \\
\hline ULomonosov & RU & 100 & 1 & 114 & $100 / 1$ & $100 / 1$ & 99.8/5 & $85.8 / 15$ & $81.7 / 29$ & $58.2 / 59$ & $43.8 / 33$ & $90.7 / 12$ & $100 / 2$ \\
\hline Tomsk SU & RU & 67.5 & 33 & 491-500 & $87.2 / 27$ & $63.7 / 41$ & $63 / 52$ & $89.6 / 13$ & $40.2 / 66$ & $17.7 / 101$ & $87.8 / 12$ & $66.7 / 29$ & 29.7/59 \\
\hline UWarsaw & PL & 87,9 & 4 & 335 & $99.6 / 5$ & $99 / 4$ & $39.9 / 101$ & $91 / 11$ & $65.6 / 46$ & 91.9/24 & $61.8 / 25$ & $40.7 / 52$ & $88.8 / 14$ \\
\hline $\begin{array}{l}\text { UKarolinska } \\
\text { Prague }\end{array}$ & $\mathrm{CZ}$ & 93,8 & 2 & 244 & 99.9/2 & $96.3 / 12$ & $40.9 / 96$ & $88.1 / 15$ & $95 / 11$ & 97.7/11 & $64.9 / 23$ & 85.8/16 & $100 / 3$ \\
\hline $\begin{array}{l}\text { METU } \\
\text { Ankara }\end{array}$ & TR & 82,1 & 9 & $401-410$ & $98.4 / 6$ & $98.5 / 5$ & 19.1/101 & $68.9 / 47$ & $99 / 5$ & $88.9 / 28$ & $33.2 / 42$ & 39.8/54 & $51.9 / 25$ \\
\hline $\begin{array}{l}\text { Eotvos Lorand } \\
\text { Budapest }\end{array}$ & $\mathrm{HU}$ & 75,3 & 15 & $601-650$ & $87.4 / 20$ & $65.4 / 38$ & 27.3/101 & $74.4 / 32$ & $83.4 / 27$ & 94.1/17 & $14.8 / 72$ & 27.9/63 & 92.9/11 \\
\hline UBucharest & RO & 68,4 & 30 & $651-700$ & $83.2 / 24$ & 95.8/15 & $22 / 101$ & $79 / 27$ & $68.9 / 45$ & $48.4 / 75$ & $19.2 / 75$ & $12.8 / 101$ & $25.7 / 70$ \\
\hline U Sofia & $\mathrm{BG}$ & 52,8 & 49 & $651-700$ & 59.5/52 & $39 / 63$ & $53.6 / 67$ & 52.7/79 & $44.6 / 62$ & $88.6 / 29$ & 0 & $40.8 / 51$ & $32.6 / 49$ \\
\hline
\end{tabular}

Table 1. Comparative positions of Kazakh universities and some of the region

R - rank 
28 • Journal of Research in Higher Education • Vol. I, No. 1, 2017

\section{QS Methodology}

\begin{tabular}{|l|l|l|}
\hline Indicators & Weighting & Source \\
\hline Academic reputation & $30.00 \%$ & Global survey of academics \\
\hline Employer reputation & $20.00 \%$ & Global survey of employers \\
\hline Faculty/student ratio & $15.00 \%$ & Institutions/public data \\
\hline Web impact & $10.00 \%$ & Webometrics \\
\hline Papers per faculty member & $10.00 \%$ & Bibliometric data from Scopus \\
\hline Staff with PhD (\%) & $5.00 \%$ & Institutions/public data \\
\hline Citations per paper & $5.00 \%$ & Bibliometric data from Scopus \\
\hline International faculty (\%) & $2.50 \%$ & Institutions/public data \\
\hline International students (\%) & $2.50 \%$ & Institutions/public data \\
\hline
\end{tabular}

Table 2. QS methodology

The following description is taken from the Methodology of QS ranking as it was presented on their website, in $2012^{1}$. Since 2013, the methodology changed, but the present paper maked use of the previous one.

\section{Academic reputation}

QS's global survey of academics has been the centerpiece of the QS World University Rankings since they were first published in 2004. In 2014 , results were based on responses from 62,000 academics worldwide.

Having provided their name, contact details, job title and the institution where they are based, respondents identify the countries, regions and faculty areas that they have most familiarity with, and up to two narrower subject disciplines in which they consider themselves expert. For each of the (up to five) faculty areas they identify, respondents are asked to list up to 10 domestic and 30 international

\footnotetext{
${ }^{1}$ http://www.iu.qs.com/product/2012-qs-word-university-rankings-supplement-2/.
} 
institutions that they consider excellent for research in the given area. They are not able to select their own institution.

\section{Employer reputation}

The QS World University Rankings are unique in incorporating employability as a key factor in the evaluation of international universities, and in 2014 it used over 27,000 survey responses to compile the results for the overall rankings. The employer reputation survey works on a similar basis to the academic one, only without the channeling for different faculty areas.

Employers are asked to identify up to 10 domestic and 30 international higher education institutions they consider excellent for the recruitment of graduates. They are also asked to identify from which disciplines they prefer to recruit. After examining where these two questions intersect, a measure of excellence in a given discipline can be inferred.

\section{Analysis of the ranking and proposals for improving the quality of the university Al Farabi and, implicitly, the position in ranking}

The performances which should be taken as targets for improving the quality of the university were highlighted with grey color in Table 1. Not only from Kazakhstan, but also from regions with similar history of development of the higher education sector and with better performances.

1. Academic reputation (30\%) and employer reputation (20\%) forms $50 \%$ of the score. First 10 universities in the ranking have over 90 points at this chapter. It is remarkable how carefully they treated the global surveys!

2. An important contribution (15\%) has the teacher/student ratio, this supposing to indicate the "quality" of education. Most of the universities in the former Soviet space, where there is a constraint in this sense, have good ratios. In Kazakhstan, as I was informed by a senior member of the Kazakh Academy of 
30 • Journal of Research in Higher Education • Vol. I, No. 1, 2017

Sciences, the universities are obliged not to exceed 12 students $/ 1$ staff.

3. The following indicators of impact are: Web impact (10\%) and Papers/faculty member $(10 \%)$; these first 5 indicators contributing with $85 \%$ of the overall score.

Focusing the analysis on these indicators one can state:

1. Academic reputation should be given by a group of elements, such as: international and joint international publications, quality of international professors and researchers, quality of international in- and outgoing students, real international relations, lobby, etc. But the reputation is biased by the fact that the respondents are mostly accepted from the region in which they live. And this is subjected to the perception of the region regarding quality. In one region, it may be that the strict compliance with the rules and regulations is the most important factor (repeated examinations, checking the homework, etc.); in another one, the scientific production might be the most important, in a third region of the world, the position of the graduates in different companies is the most important. So, this indicator is too subjective to be given such a weight. In an analysis of the Centrum für Hochschulentwicklung (CHE) in Germany, it was demonstrated that the reputation does not go necessarily along with the scientific contribution of the university (Berghoff \& Federkeil 2006).

2. Reputation among employers, of course, is given primarily by the quality of the graduates (what they know, and how they perform what they are asked to do, etc.) but it is also helped a lot by the university, through supplying the QS team with a comprehensive list of reputed employers; and this is possible through a good networking via the Alumni Association. Because Kazakhstan is a country rich in resources, many international companies are opening branches in the country and many graduates are employed there.

Concerning these two indicators, I cannot help quoting our colleagues from CHE (Berghoff \& Federkeil 2006), who, after studying the correlation between reputation and research \& innovation force of the university state the following: „Reputation can be a useful 
information in rankings as it reflects existing reputation hierarchies that are a social fact and it is an information students want to know, but only when the validity and reliability is guaranteed but due to its characteristics and limitations it should not be used as an element of a weighted overall score. As normally differences in values are so small in particular in the lower range - it should not be transformed into league table positions".

In what these two indicators are concerned, Al Farabi is placed remarkably well.

1. Analyzing the third indicator in the order of weight: student/teacher ratio is advantaging the universities with small working groups, mainly the technical and scientific universities. It is rational for a science and technology program to have a ratio of around 10-15 students/teacher, for arts 1-3, for medicine 310 , for social sciences and humanities, 20. Very often, the finances of the university do not allow to follow these ratios. Al Farabi should improve in what this indicator is concerned if the finances allow it.

2. The scientific productivity expressed through SCOPUS registered papers/faculty member is a sign of quality of the staff, as well the citations/paper; an academic who does not produce research is not really a good teacher, because it conveys knowledge only form other's experience and not their own. The score for this indicator, at some top universities like University Charles from Prague is 0.95 , for University of Budapest 0.83 , for the University of Bucharest 0.57. Through a simple interpolation, judging the score of University Al Farabi, the productivity is 0.04 ! Regarding the other qualitative indicator (citations/paper), the QS weight is so small (5\%) that it does not encourage actually the increase of quality.

3. The figures for international students and international professors are quite good, but I suggest here to try to attract international professors with scientific performance (international ISI/SCOPUS papers, books in internationally recognized editing houses), with the knowledge of growing scientists around them. 
32 • Journal of Research in Higher Education • Vol. I, No. 1, 2017

\section{How can Al Farabi University improve its activity based on rankings?}

Theoretically, we should dig into the score calculation methodology, but most of the methodologies, do not respect the Berlin Principles of University Rankings. They only describe in general lines how they calculate the scores. The same happens with the QS ranking. We may make an assumption: with the exception of ARWU, a ranking which uses a logarithmic scale in calculations of the scores, the other rankings use linear relationships (e.g. URAP). So a linear extrapolation should not be far from reality.

We can get simple information at a first glimpse. We choose one university not far from the one analyzed: Al Farabi (AF), compared with University of Bucharest (UB).

We know the data from 2014 from the University of Bucharest: academic staff - 1,335 (Romania SCOPUS); SCOPUS documents - 758; SCOPUS citations - 4,237 (www.edu.ro).

So, the parameters for UB are 0.57 paper/staff and 5.58 citations/paper.

For AF, the calculation, using a linear relationship, results in 0.04 papers/staff and 1.4 citations/paper. It means that AF has to improve 14 times as publication productivity and 4 times as citations/paper. For sure, this comes from the Soviet tradition that research institutes are doing research and universities only teach. But this is not the case right now. Consequently, the top management of the university has to take measures to motivate staff to publish much more (an internal analysis can show where the smallest productivity and production is) and to publish in journals with higher impact factor which attract more citations (an internal analysis can show which are the most suitable journals in which to publish in each field of the university). Another measure can be to affiliate one Institute of Research with full time researchers. A special policy of motivation and engagement of the staff has to be drawn, assuring a climate of transparency and meritocracy, creating an environment which stimulates innovation, creating good research conditions, not excluding additional remuneration. In this way, in 5-7 years, Al Farabi University can improve a lot in these areas. 


\section{Conclusions}

In the world there are about 30,000 higher education institutions and about 17,000 universities. The QS ranking assesses among 4,000 higher education institutions and ranks about 800. University Al Farabi has a good position in QS ranking which is the merit of the administration of the institution and of the staff and students. The presence in one global ranking on a visible good position is a good result and can be a good conveyor of image. It can contribute seriously to the reputation of the university. The university has to take this opportunity seriously. Rankings do show where the university is, in comparison to others, but do not show how they can reach certain higher positions in the league tables.

However, it should be careful with what real quality means: it means good professors, good students, good research, good teaching and research equipment, good research and administrative staff, a general climate of stimulation the development and innovation. (Figure 1).

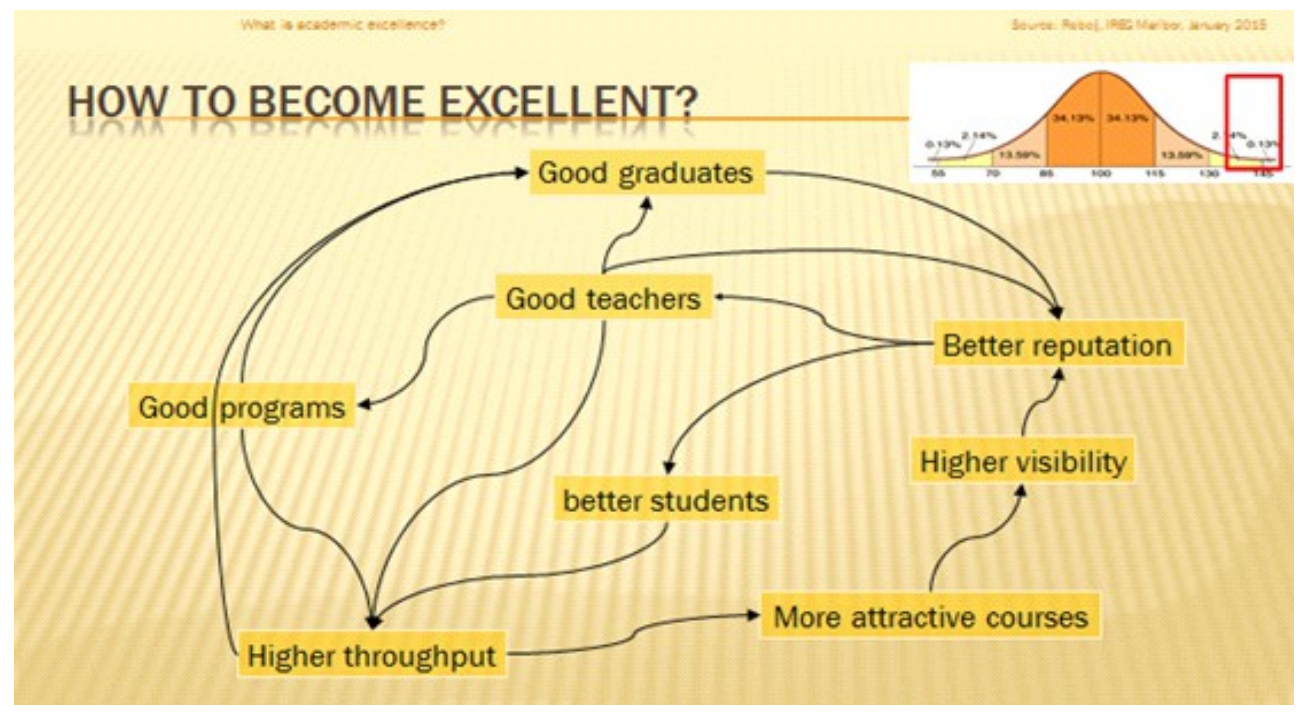

Figure 1. Quality of a university (Source: Rebolj 2015) 
The contribution of a university to the development of a country is mainly measured through the quality of the graduates, the way they contribute to the development of the society and economy, the quality of research and innovation in the university.

I am very sure some of the graduates of Al Farabi are very good and perform well where their job is. The university has to increase the number of high quality graduates. But also to increase the quality of research and innovation. In URAP ranking, based only on research performances, Al Farabi is on $1967^{\text {th }}$ position in the world and Lev Gumiliov on $1699^{\text {th }}$ position. Among the 1352 institutions from Asia which are included in the Scimago ranking (exclusively based on research production), there is none from Kazakhstan! Al Farabi should be careful about this aspect and treat it with consideration.

In short, if one really understands rankings, one can use them for improvement. 


\section{References}

Agachi P. S., Bucur I. (2009). Programul UBB 500 al Universității Babeș-Bolyai, Quality Assurance Review for Higher Education, ARACIS, 1 (2): 156, http://www.aracis.ro/fileadmin/ARACIS/Revista_QAR/Decembrie_200 9/Agachi.pdf.

Agachi P. S., Nica P. , Moraru C. (2012), "Universities Ranking as Stimulus for Quality Enhancement. Case Study of Romania", World Class Universities, in University Ranking as Stimulus for Quality Assurance, CEPES UNESCO, EFES, University Babes-Bolyai, ClujNapoca.

Agachi, P. S. (2008). Profiling the University as Key Actor on the European HE Scene, ESMU DEAN Conference, 16-18 Nov. 2008.

Agachi, P. S. (2009). How to Convince a University to Become a Research World Class University, UNICA Rector's seminar, The Role of Evaluation and Ranking of Universities in the Quality Culture, Dubrovnik, July 3-4, 2009.

Agachi, P. S., Moraru Camelia (2005). Performanţe şi clasificări instituţionale. Metodologie de aplicare, UNESCO CEEPES, 22 Martie 2005, Bucharest.

Agachi, P.,S. (2011). University Rankings - An Instrument for Quality Management, The 3rd Annual Symposium on University Rankings and Quality Assurance in Europe, Center for Parliamentary Studies, Brussels, April 14, 2011.

Agachi, P.,S., Moraru, C., Cramarenco, R., Curaj, A. (2009). Is Developing Elite Universities a Top Priority Agenda for HE in Romania? Analyses of the Evolution of the HE Sector's Priorities and Romanian Top universities strategies in developing excellence in research, WCU - 3 Conference, Nov. 2-4, 2009, Shanghai.

Agachi, P.S., Moraru, C., Mihaila, A., Nica, P.. (2007). "Ierarhizarea universităților din România din punct de vedere al activității de cerecetare științifică", Revista de Politica Științei și Scientometrie, 2007 (4): 154. http://uefiscdi.gov.ro/UserFiles/File/CENAPOSS/nr. \%204.\%202007.pdf.

Al Farabi University in Almaty, http://www.kaznu.kz/en/. 
36 • Journal of Research in Higher Education • Vol. I, No. 1, 2017

Berghoff, Sylvia, Federkeil, G. (2006). Reputation Indicators and Research Performance, Second Meeting of the International Ranking Expert Group, May 18 - 21, 2006, Berlin.

Berlin Principles on Ranking of Higher Education Institutions, http://www.che.de/downloads/Berlin_Principles_IREG_534.pdf.

Dumitru, M., Iordache-Platis, Magdalena, Moraru, Camelia, Cramarenco, Romana, Agachi, P.S. (2013). The Road to World Class University Status. The Case of University of Bucharest, WCU- $5^{\text {th }}$ Conference, Shanghai, 3-6 Nov. 2013.

Nica P. (2000), Managementul calităţii şi ierarhizarea universităţilor românești, București: Paideia, pp. 68 - 237.

QS University Rankings, 2012 Report, http://www.iu.qs.com/product/2012qs-word-university-rankings-supplement-2/.

Rauhvargers Andrzej (2011), Global University Rankings and Their Impact, European University Association, Brussels, 2011.

Rebolj, D. (2015) What is Academic Excellence?, IREG Forum, Maribor, 19-20 January 2015.

Romania SCOPUS Ro dataset 2009 - 2014, Report ANELIS, 2015.

Romanian Ministry of National Education, Situația personalului didactic, didactic auxiliar și de cercetare, personalul TESA din universităţile de stat la data de 1.10.2014, www.edu.ro. 